MICHAIL VASILEVICH NEMCHINOV

e-mail: uchsovet@madi.ru

ANNA GENNADIEVNA IVANOVA

e-mail: ag.vasileva@gmail.com

MADI, 64, Leningradsky Prosp., Moscow, 125319, Russia
Manuscript submitted 2018.03.05 - revised 2019.01.02, initially accepted for publication 2019.09.09, published in September 2019

\title{
DECREASING THE HEIGHT OF MOTOR ROAD EMBANKMENTS BY CHANGING THE PRINCIPLE OF WATER FLOW AND SNOW PROTECTION IN THESE CONDITIONS
}

\section{ZMNIESZENIE WYSOKOŚCI NASYPÓW SAMOCHODOWYCH POPRZEZZMIANĘ ZASADY PRZEPEYWU WODY I OCHRONY PRZED ŚNIEGIEM}

DOI: $10.30540 /$ sae-2019-015

\begin{abstract}
The article puts forward a new type of culverts in roads. Main motive behind the construction of the new type of culverts is presented and examined: considerable height of road-beds at their construction locations and, as a result, unreasonably high road embankments. Snow drifts at roads and possible protection means are also examined. A report on theoretical analysis of the reasons of snow drifts experimental study with road models is included. The model showed low and high drifts blowing at different speeds at roads with and without embankments and with and without a snow-retaining barrier. All experiments were first conducted without cars on the traffic-bearing surface of the road, then with cars. Recommendations regarding road protection against snow are given.
\end{abstract}

Keywords: water flow, waterless valleys, culvert, speed, flow rate, model, modelling criteria, hydraulic experiment, snow-drift, snow-fall, wind velocity, snow-protection, snow removal, roadway, car, traffic, model, experiment

Streszczenie

Artykut przedstawia nowy typ przepustów na drogach. Przedstawiono w nim i zbadano główny motyw budowy nowego typu przepustów takie jak: znaczna wysokość koryt w ich miejscach budowy i ich konsekwencja w świetle nieuzasadnionych wysokich nasypów drogowych. Badane zostały również zaspy śniegu na drogach i możliwe środki ochrony. Uwzględniono raport z teoretycznej analizy przyczyn na podstawie eksperymentalnych badań nad zaspami śnieżnymi, wykorzystując modele drogowe. Niniejszy model pokazat niskie $i$ wysokie zaspy z uwzględnieniem wiatrów wiejacych z różnymi prędkościami na drogach z nasypami i barierami przeciwśnieżnymi oraz przypadek bez nich. Wszystkie eksperymenty przeprowadzono najpierw bez samochodów na nawierzchni drogowej, a następnie z samochodami. Przedstawiono zalecenia dotycząe ochrony dróg przed śniegiem.

Słowa kluczowe: przepływ wody, doliny bezwodne, przepust, prędkość, prędkość przepływu, model, kryteria modelowania, eksperyment hydrauliczny, dryf śniegu, opad śniegu, prędkość wiatru, ochrona przed śniegiem, odśnieżanie, jezdnia, samochód, ruch drogowy, model, eksperyment

\section{INTRODUCTION}

Lack of soil for the construction of road structures and for construction of road-beds has become a major (and in many cases primary) concern during the construction of new motorways. It causes long delays in the construction of new roads. Sometimes these delays are measured in years. Codes and standards have long since excluded recommendations concerning construction of road-beds with zero embankments. Highway engineer's handbook mentions this type of road profile only ones and gives no further description of it later on [1-4].

In this study we look at the task of decreasing the height of embankment by refining small culvert 
structures. This article will examine, first, changing approaches to hydraulic engineering, and second changes in snow drifts related to the decrease of the embankment height [5-8].

Crossing over small streams and dry gaps (seasonal streams) requires construction of small culverts small bridges, pipe-culvers and other types of road hydraulic structures. Their number is high not only on rough terrain but even on level grounds - there is at least one of them per each road kilometre. Construction of small culverts is closely connected to the problems related to the construction of road-beds of motorways, especially with the automatization of the design process, when it is during the design process that reference points of longitudinal road profile are determined that are later used to set up or create the longitudinal profile of the road. Project line determines elevation of the road-bed and, therefore, the demand for soil for its construction and, in the long run, construction cost. Road-bed elevations over small culverts constitute some of these reference points. These elevations are sums of the stream bed elevation, height of the structure (culvert pipe) and height of the soil cover above the pipe. Standard minimum ID is $1 \mathrm{~m}, \mathrm{OD}-1.2 \ldots 1.3 \mathrm{~m}$, and soil cover above the pipe is at least $0.5 \mathrm{~m}$ thick (Fig. 1) [9-10].

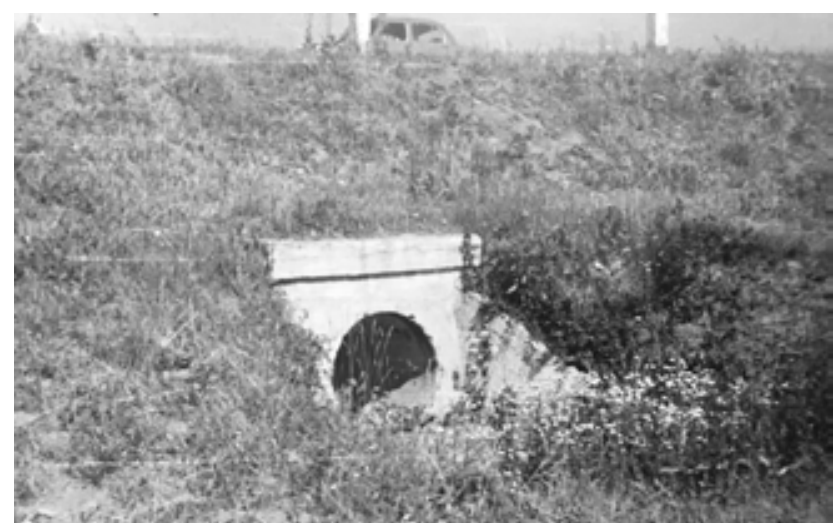

Fig. 1. Road-bed and pipe culvert at $\mathrm{km} 122+629$ of Moscow-Voronezh motorway. Pipe diameter $0.75 \mathrm{~m}$

This embankment shall therefore be at least $2 \mathrm{~m}$ high. As a result the road-bed is formed on an embankment that is unreasonably high. Construction of motorways along the whole of their length on embankments, i.e. as a systematic construction method at level terrains, causes substantial damage: it cuts territories into separate isolated areas; damages hydraulic geology of the adjacent territory. It also affects flora and fauna; requires an enormous about of soil and installation of numerous soil banks. Ways shall be sought to decrease the height of embankments at level terrains. One of the solutions is to decrease construction height of road-bed at small culverts [11-13].

On the other hand as height of the embankment is decreased the snowdrift problem becomes more prominent. Though the climate is changing, its winter meteorological phenomena remain the same. So that the main reason of snow drifts on roads - snow fall from the clouds (snowfalls) and relocation of snow onto the roads (blizzards) remain. Theoretical base for the protection of roads against snow drifts is strong and, what is more important, has been tested in practice on motorways for decades [14-16].

Everything stays the same but for one thing. It was established that examination of snow protection measures, development of snow protection and snow removal systems, its testing were carried out during the time when the traffic load was very low. In the past, there were very few cars on the roads, while nowadays the traffic is dense, both in winter and in summer. The traffic effectively serves as an barrier preventing snow transport that did not exist before. As a result, aerodynamics of snow flow over the road-bed has changed drastically - from structure well streamed by the air flow it has transformed into a poorly streamed structure. Road bearing surface now bears a snowretaining barrier - a fence - made up of cars that retain snow and air flow which leads to snow deposition.

\section{THEORETICAL ANALYSIS OF THE WATER FLOW}

Culverts construction practices have adopted a principle of narrowing the potential floodwater flow [14]. It is based on the fact that the opening of the culvert is narrower than the width of the potential water flow. The smaller culvert opening ( $1 \mathrm{~m}$ diameter as a rule) results in an accumulation of water in front of it and flooding of a considerable part of waterbed. With a considerable embankment height. This almost inevitably leads to local washout of the downstream channel.

Water flow widening before the motorway roadbed means that a small culvert shall be constructed with an opening as wide as the water flow width. With discharge capacity at the same level the height of the opening can be lowered, as can the height of the embankment. We shall call it flattened structure.

The main advantage of building such structure is that the reference elevation for the design of longitudinal profile can be lowered and, as a result, the road-bed height may decrease so much that the road can be constructed at 'elevation zero' (see Table 1). 
Table 1. Possible change in height of the embankment and amount of imported soil for the construction of embankment of Moscow - St. Petersburg road and Central Ring Road around Moscow after construction of flattened culverts.

\begin{tabular}{|c|c|c|c|c|c|c|}
\hline \multirow{3}{*}{$\begin{array}{l}\text { Road parameters } \\
\text { and construction characteristics }\end{array}$} & \multicolumn{4}{|c|}{ Moscow - St. Petersburg motorway } & \multirow{2}{*}{\multicolumn{2}{|c|}{$\begin{array}{l}\text { Central Ring Road } \\
\text { km 7-10, 31-35 }\end{array}$}} \\
\hline & \multicolumn{2}{|c|}{ km $549-556,5$} & \multicolumn{2}{|c|}{ km $562-572$} & & \\
\hline & Project & Proposed & Project & Proposed & Project & Proposed \\
\hline Length of embankments, $\mathrm{m}$ & 7500 & 5175 & 10000 & 7385 & 4849 & 3860 \\
\hline Length of excavations, $\mathrm{m}$ & 0 & 2325 & 0 & 2615 & 2151 & 3140 \\
\hline $\begin{array}{l}\text { Average position point of the top of the } \\
\text { traffic bearing surface, } m\end{array}$ & 2.61 & 0.07 & 2.47 & 0.51 & 1.01 & 0.64 \\
\hline $\begin{array}{l}\text { Average position point of the top of the } \\
\text { road-bed, } m\end{array}$ & 1.67 & -0.87 & 1.53 & -0.43 & -0.03 & -0.37 \\
\hline Road mat thickness, m & 0.94 & 0.94 & 0.94 & 0.94 & 1.04 & 1.04 \\
\hline Average depth of the excavation, $m$ & - & 0.16 & - & 0.11 & 1.99 & 1.90 \\
\hline $\begin{array}{l}\text { Amount of soil for embankment, } \\
\text { thousands of } \mathrm{m}^{3}\end{array}$ & 438.37 & 154.39 & 612.09 & 195.43 & 736.88 & 438.64 \\
\hline $\begin{array}{l}\text { Amount of soil from excavations, } \\
\text { thousands of } \mathrm{m}^{3}\end{array}$ & 0 & 161.780 & 0 & 204.18 & 193.036 & 266.16 \\
\hline Amount of imported soil, thousands of $\mathrm{m}^{3}$ & 438.38 & 0 & 612.1 & 0 & 543.85 & 172.48 \\
\hline $\begin{array}{l}\text { Soil removed from construction site, } \\
\text { thousands of } \mathrm{m}^{3}\end{array}$ & 0 & 7.39 & 0 & 8.75 & 0 & 0 \\
\hline Number of zero elevations, pcs. & 0 & 19 & 0 & 30 & 12 & 15 \\
\hline Number of culverts, pcs. & 7 & 2 & 4 & 3 & 9 & 6 \\
\hline Length of roadside ditches, $\mathrm{m}$ & 7500 & 9462 & 7500 & 9462 & 5462 & 8650 \\
\hline
\end{tabular}

Note. The number of culverts has been decreased because of a change in the organization of surface runoff drain.

Reverse is also possible - "the road" may serve as a supplier of soil (from excavations and draining ditches) for the construction of embankments as the roads cross deep stream beds and other low terrain areas.

Modification of the construction principle of small culverts calls for certain changes in construction related to the hydraulics of the water flow. In the examined case intake stream bed coming up to the road-bed required widening the culvert to the required size. Decreasing the height of the culvert is limited by the requirement to clean it to remove water flow sediments. Small longitudinal slopes of shallow stream beds together with vegetation slow down the water flow and, consequently, the water flow carrying capacity. Coarse contaminants in accordance with operation (maintenance) rules for small culverts shall be removed by the road services. Hence, the minimum height of a culver can be limited to $0.3 \ldots 0.4 \mathrm{~m}$.

Flattened culvert can operate (preferably) without pressure or pressurized. The latter alternative is worse as it will create additional pressure and flood the roadbed and increase the speed of water at the exit of the structure.

As the stream bed widens so does the water flow (it spreads), its depth and flow speed decrease as the flow rate becomes constant (see Fig. 2). 


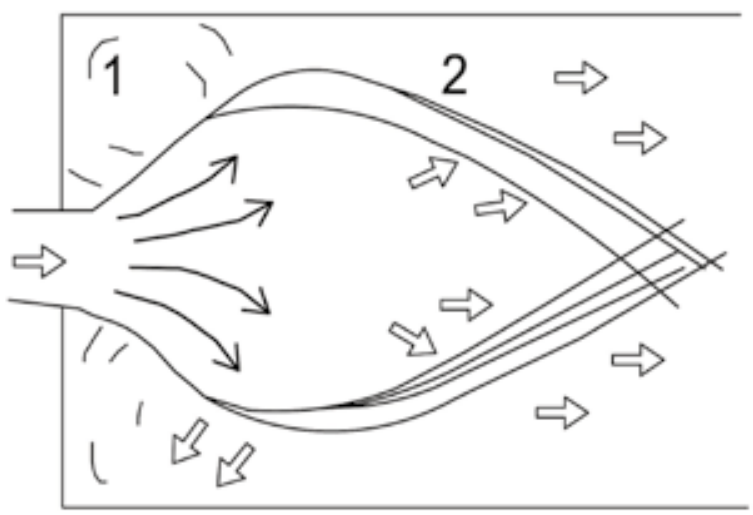

Fig. 2. Spread of a turbulent water flow in wide river beds: 1 -eddy current; 2 - angled hydraulic jump waves.

It is achievable that water flow speed becomes so low that it does not erode soil. The stream bed widening area shall be long enough to allow for a smooth widening of the water flow till it reaches the spreading width.

With a high accuracy at the first approximation for the cross-section of the water flow coming from the natural stream bed to the widening area specific water flow velocity $\mathrm{E}$ can be calculated using a formula (1):

$$
E=\beta \cdot h_{\text {out }}+\frac{\alpha \cdot V_{o u t}^{2}}{2 g}
$$

where: $\beta$ - potential energy coefficient taking into account non-hydrostatic distribution of pressure at the exit section; $h_{\text {out }}, V_{\text {out }}$-depth and speed of water flow at the exit section, respectively. If the shape of the cross section at the stream bed part of the lowland is close to a circle (like that of a pipe) $\beta$ coefficient during non-pressurized flow and filling of the stream bed $h_{0}(D=[0.1 \ldots 0.5)]$ is equal to $[0.5 \ldots 0.6](\mathrm{D}$ diameter of an equivalent pipe, $h_{0}$ - depth of the water flow at the stream bed of the lowland).

As with small bridges the depth of a flow at the outlet section is calculated using Bernoulli's equation. Numerous studies show that before the water flow leaves the lowland and enters its widened part an area forms where the water surface level is lower lout $=$ $[3 \ldots 4] \times h_{\text {out }}$.

For this area, disregarding (due to their small values) the changes in slope and friction forces the following equation can be made (2):

$$
h_{1}+\frac{\alpha \cdot V_{1}^{2}}{2 g}=\beta \cdot h_{\text {out }}+\frac{\alpha \cdot V_{\text {out }}^{2}}{2 g}
$$

\begin{tabular}{|c|c|c|c|c|c|c|c|c|c|c|}
\hline \multirow{2}{*}{$\mathbf{Q}, \%$} & \multirow{2}{*}{ Coordinates } & \multicolumn{9}{|c|}{ Lines of the same depth } \\
\hline & & 0.9 & 0.8 & 0.7 & 0.6 & 0.5 & 0.4 & 0.3 & 0.2 & 0.1 \\
\hline \multirow{2}{*}{0} & $\mathrm{x} / \mathrm{b} \mathrm{Fr}{ }_{0}$ & 0.050 & 0.150 & 0.280 & 0.400 & 0.500 & 0.600 & 0.730 & 0.860 & 0.110 \\
\hline & $y / b$ & 0.503 & 0.510 & 0.530 & 0.565 & 0.620 & 0.675 & 0.760 & 0.870 & 0.100 \\
\hline \multirow{2}{*}{10} & $\mathrm{x} / \mathrm{b} \mathrm{Fr}$ & 0.165 & 0.205 & 0.460 & 0.610 & 0.790 & 1.000 & 1.210 & 1.660 & 2.770 \\
\hline & $y / b$ & 0.405 & 0.420 & 0.450 & 0.500 & 0.575 & 0.690 & 0.820 & 1.110 & 1.980 \\
\hline \multirow{2}{*}{20} & $\mathrm{x} / \mathrm{d} \mathrm{Fr}_{0}$ & 0.270 & 0.430 & 0.610 & 0.780 & 0.970 & 1.220 & 1.590 & 2.140 & 3.790 \\
\hline & $y / b$ & 0.310 & 0.330 & 0.360 & 0.410 & 0.480 & 0.580 & 0.750 & 1.020 & 1.840 \\
\hline \multirow{2}{*}{30} & $\mathrm{x} / \mathrm{b} \mathrm{Fr}{ }_{0}$ & 0.370 & 0.530 & 0.710 & 0.880 & 1.060 & 1.360 & 1.800 & 2.460 & 4.370 \\
\hline & $y / b$ & 0.210 & 0.230 & 0.250 & 0.290 & 0.350 & 0.440 & 0.560 & 0.770 & 1.360 \\
\hline \multirow{2}{*}{40} & $\mathrm{x} / \mathrm{b} \mathrm{Fr}$ & 0.450 & 0.590 & 0.750 & 0.920 & 1.120 & 1.430 & 1.910 & 2.690 & 4.770 \\
\hline & $y / b$ & 0.115 & 0.125 & 0.140 & 0.160 & 0.190 & 0.230 & 0.300 & 0.410 & 0.760 \\
\hline \multirow{2}{*}{50} & $\mathrm{x} / \mathrm{b} \mathrm{Fr}{ }_{0}$ & 0.480 & 0.610 & 0.770 & 0.940 & 1.130 & 1.450 & 1.950 & 2.760 & 4.940 \\
\hline & $y / b$ & 0.0 & 0.0 & 0.0 & 0.0 & 0.0 & 0.0 & 0.0 & 0.0 & 0.0 \\
\hline
\end{tabular}

Table 2. Coordinates of the flow lines and lines of the same depth () for the graph in Fig. 4.

Note. $\mathrm{Fr}_{\text {out }}=\mathrm{Fr}_{\mathrm{o}} ; \mathrm{b}-$ depth of the flow (stream bed) as it enters the widening area; $\mathrm{x}-$ distance along the water flow, $\mathrm{y}-$ distance across the water flow. 
After all modifications have been made we get the following final design formula (3):

$$
\eta=\frac{\left[1-\frac{\prod_{k 1} \cdot\left(1-\frac{w_{1}^{2}}{w_{\text {out }}^{2}}\right)}{2}\right]}{\beta}
$$

where: $\Pi_{k 1}=\alpha \times V^{2} 1 \div g \times h$; ratio $w_{\text {out }}{ }^{2} / w_{1}{ }^{2}$ is substituted with ratio $w_{1}{ }^{2} / w_{t}^{2}=w_{\text {out }}{ }^{2} / v_{1}{ }^{2} \times \eta=h_{\text {out }} / h_{1}, W$ - area of the cross-section of the flow in corresponding crosssections. $\mathrm{b}-$ values $\mathrm{h}_{1}$ and $\Pi_{\mathrm{k} 1}$ at lowland slopes $i_{0}>i_{\mathrm{k}}$ for the considered case are equal: $h_{1}=\underline{h}_{0} ; \Pi k_{0}=F r^{2}$ (taking into account large length of the lowland), $F r=V^{2} / 2 \mathrm{~g}-$ Froude number for section 1 .

During calculation of the flow spreading I.A. Sherenkov's graph is used. We shall calculate $F r_{\text {out }}=V_{\text {out }} / \mathrm{V} \times h_{\text {out }}$ and for flow axis (axis X) using Table 2 we find ratio for flow depths at different distances from the outlet cross-section.
The provided data illustrates that hydraulic calculation can be used to project the required conditions of water flow as it approaches the culvert.

At the outlet of the structure the width of the stream is the same as the width of the opening. Water flow speed of a single-span structure is almost the same as the water flow speed at the inlet point. This speed has decreased due to the widening of the stream. Thus, the stream does not have to be further spread. If required and if the soil of the stream bed fits for the purpose the speed at the outlet of the structure may be lowered down to one that does not erode the soil of the stream bed.

\subsection{Experimental study results}

To assess the spread of the water flow visually a hydraulic experiment was conducted at an inlet part of the stream bed. The scale of geometric simulation is 1:2. At the model the width of the inlet stream bed is $0.60 \mathrm{~m}$; water flow speed at the outlet cross-section is $0.860 \mathrm{~m} / \mathrm{s}$; water flow rate is $0.01548 \mathrm{~m}^{3} / \mathrm{s}$. With Froude scaling this corresponds to the actual flow $1.2 \mathrm{~m}$ wide at the outlet cross-section with water flow speed of $1.216 \mathrm{~m} / \mathrm{s} V n^{2}=$ $\mathrm{Vm}^{2} \times \mathrm{hWhm}$ and flow rate of $1.459 \mathrm{~m}^{3} / \mathrm{s}$.
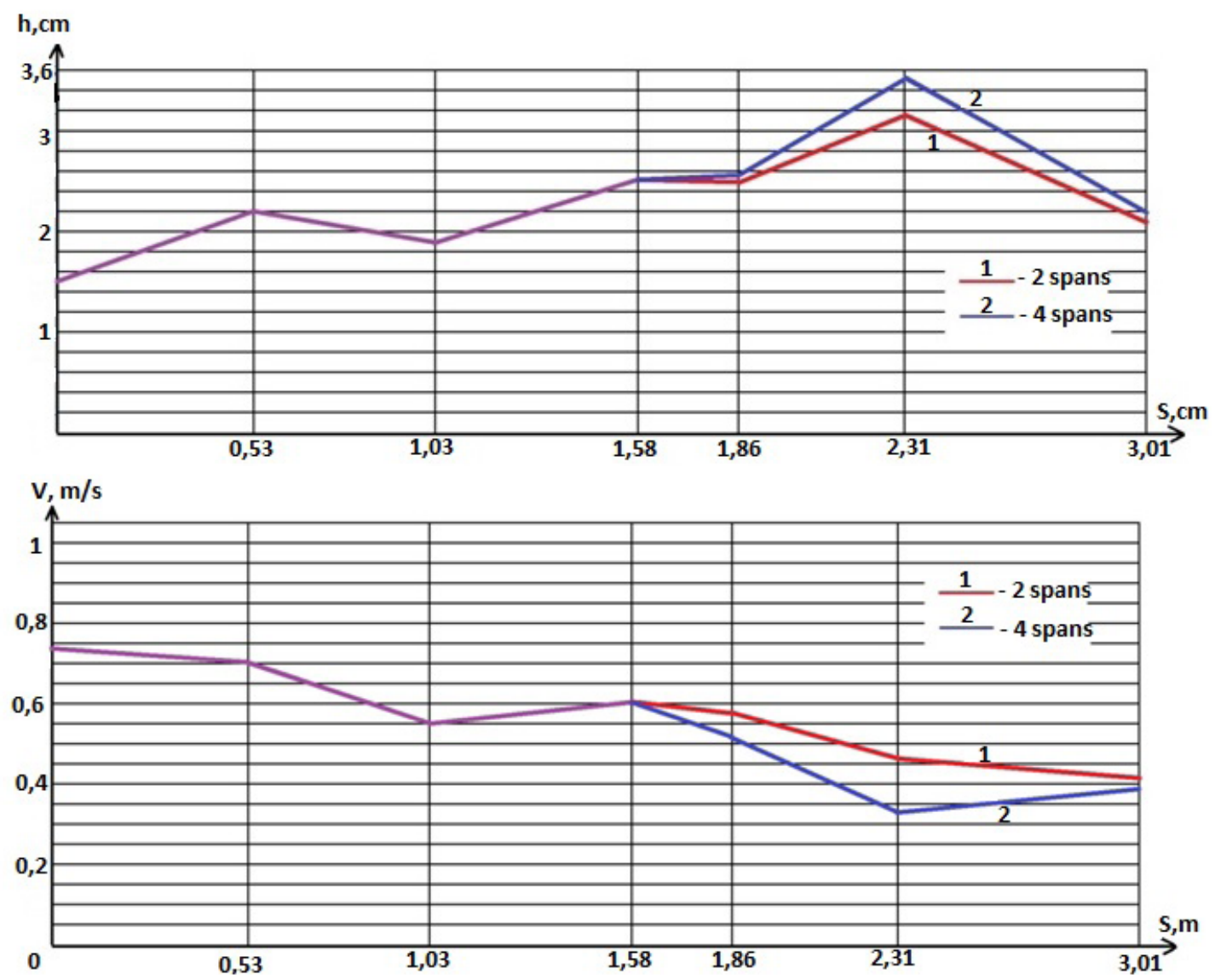

Fig. 3. Graphs showing change in the level of open water surface and water flow along the flow axis at its widening area 
The model length of the stream widening area ( $1 p$ ) was $1.05 \mathrm{~m}$ which corresponds to the actual length of $2.10 \mathrm{~m}$. Therefore, in accordance with the diagrams (see Fig. 3) the length of the stream bed widening are at the inlet of small culvert I shall amount at least to the sum of $1 \mathrm{p}+1 \kappa$.

\subsection{Partial consclusions}

Theoretical and experimental studies lead us to the following conclusions:

- Construction of flattened small culverts by decreasing their construction height allows for a considerable (sometimes, total) decrease the demand for imported soil for the construction of road-bed, which makes it cheaper and easier (organization-wise) to construction a motorway.

- A new method of construction of small culverts have been proposed that is based on widening the streambed of the water flow as it approaches the culvert (instead of narrowing it). This method required individual approach and increasing hydraulic calculation of water flow parameters for each individual case, more serious approach to the collection of hydraulic data for the formation of water flow during floods period brought about by the necessity to prepare (widen) the intake channel.

- Adoption of flattened culverts in designs requires a review of the road runoff drainage. Standard construction of side catch water drains shall be supplemented with a development of a spatial system of intake and removal of runoff from the road-bed of motorways. During the development of such drainage system the area adjacent to the road shall be examined and watercourses, waterless valleys, lowland areas shall be identified where during flood periods the runoff may be diverted to to avoid building culverts at flat land.

Small flattened culvert with proper design can be built without reinforcing outlet stream bed (but for the natural or planted vegetation) - if by widening the inlet (and, therefore, outlet) stream bed water flow speed can be decreased to the level wen it no longer erodes the soil of the stream bed. Outlet stream bed can also be reinforced with rock fill.

\section{SNOW DRIFTS PHENOMENON INVESTIGATION}

Russia is a northern country with long winters, low below-zero temperatures, harsh winds, snow falls and snowstorms. Hence, it has a vast experience successfully preventing and removing snow drifts from auto roads. In recent years, however, it has become clear that all this is no longer enough: the main auto roads equipped with powerful snow removing systems and protection means against snow drifts witness prolonged many kilometres long traffic jams caused by snow drifts on the traffic bearing part of auto roads. This means that old, tried-and-true methods and ways do not suffice any more. Why is that?

\subsection{Methods of investigation}

In order to answer this question we need to analyse a lot of different factors. A number of methods has been used - both theoretical and experimental - to tackle different aspects of the problem, to collect, to generalize and to analyse the knowledge and experience base of road winter maintenance. Facts about winter meteorological natural phenomena snow-falls, snow-storms, snow physical properties in air and on the road surface, with traffic, have been reaffirmed. It was collected known information about air dynamics of road-bed - in embankment, pocket, at ground level. Then it was established how roads behave with the snow-storm protection - snow protective facilities: snow cover, hurdles, fences, windrows, snow trenches and guard walls. Snow removing methods were also studied. Air dynamic experiments were made using models.

Model analysis criteria: Newton's condition $(\mathrm{Ne})$ : $F_{n} \ln / M_{n} V_{n 2}=F_{m} \operatorname{lm} / M_{m} V_{m} V_{m 2} ;$ Froude number $(F r)$ : $V_{n 2} / g l_{n}=V_{m 2} / g l_{m} ;$ Reynolds number: $\ln V_{n} / v_{n}=l_{m} V_{m} /$ $v_{m}$. Strouhal number: $\ln /\left(V_{n} t_{n}\right)=\operatorname{lm} /\left(V_{m} t_{m}\right)$ and Euler number: $p_{n} / \rho_{n} V_{n 2}=p_{m} / \rho_{m} V_{m 2}$ have been analyzed. Froude $(F r)$ and Reynolds $(R e)$ numbers were chosen as primary ones. Based on the examination of the criteria geometrical $(\alpha l)\left(\alpha v=\alpha l \frac{1}{2}\right)$ model analysis scale has been chosen. The issue of air flow solid discharge model analysis has also been reviewed based on the drifts model analysis: $R e=V / W_{o}=$ idem, $V_{2} / g d=$ idem, $\operatorname{Re}>\operatorname{Red}$. Saturation $(S)$ of the air flow with solid particles was evaluated using the following equation $S=0.009\left(V_{k p} / W_{o}\right) 6(d / D) 3.5$. (Where: $M=$ mass, $v$ - viscosity, $\rho$ - density, $p$ - pressure drop, $t$ time, $V_{k p}$ - speed required to transport a set number of suspended-state solid particles of a certain grain-size composition, $W_{o}$ - settling velocity of solid particles).

Road-bed (embankment height), cars and air flow (turbulence, speed) were used for model analysis. Deposition of drifts from air flow has been evaluated qualitatively. 


\subsection{Study results. Theoretical analysis}

A lot of information has been collected that cannot be covered by a short study like this one. For that reason a monograph Snowdrifts on the Roads and Snowdrift-Protection under Modern Conditions has been compiled and is pending to be published at the moment.

The study showed that the main factors causing snowdrifts remain the same, although the climate is gradually changing its winter meteorological phenomena don't. That is why the main cause of snowdrifts on roads is snowfalls and snow relocation to the roads (during snowstorms). Snowdrift protection measures are very well studied in theory and, more importantly, have been tested for decades in practice - on the roads.

All but one thing stays the same: it has been established that snow protection issues, development of snow-protection and snow-disposal systems and their testing took place when the road traffic was very low. In the past roads carried very few cars, while nowadays they are subject to heavy traffic flows both in winter and in summer seasons. A structure preventing snow from drifting over the road appeared in the middle of the roads, that hadn't been there before. As a result the air dynamics of the air flow above the body of the road has changed drastically - roads that used to be a structure easily bypassed by the air flow now cannot be bypassed. Cars form a snow retaining barrier that detains wind and snow flow and causes snow falls. Snow ploughs mainly clean the motorways and sides of the roads from snow that falls from the skies. The snow that is transferred to roads during snowstorms accumulates because of traffic flow. The time for snow removal has been cut substantially as there are hardly any breaks in traffic flow apart from night time. Traditional snow cleaning process requires a group of snow ploughs. Their operating speed is not very high, and is considerably lower than the speed of cars. This holds back the traffic and creates long rows of cars. Hence, snow cleaning works obstruct the movement of the cars. As a rule, snow-cleaning operations are conducted at $30 \ldots 40 \mathrm{~km} / \mathrm{h}$. Snow is not thrown far from the traffic-bearing surface of the road, instead it is, at best, pushed next to the edge of the road-bed like a dam that also contributes to the retention of snow during snowstorms.

\subsection{Experimental study}

Motorway road-bed has been analysed using a 1:60 scale model set at ground level and on an embankment (model $-\mathrm{cm}$, actual height $-1.8 \mathrm{~m}$ ) and operating during ground blizzard with wind flow speed ranging from 5.0 to $1.3 \mathrm{~m} / \mathrm{s}$ (actual speed $38.7 \ldots 10.1 \mathrm{~km} / \mathrm{h}$ ) with and without a snow barrier to the windward side of the road. Traffic-bearing surface of the road has two traffic lanes where: cars are present; cars are present and are moving in one row (take up one lane), are present and are moving in two rows (take up two lanes). A snow imitating material was added to the air flow.

For the study results for models see Figures 4-8.

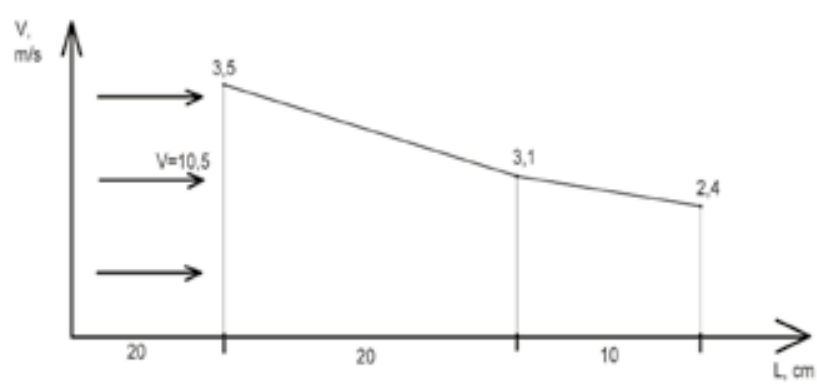

Fig. 4. Graphs reflecting change in speed of the air flow over the road-bed with no cars on the traffic-bearing surface: a) without snow shield; b) with a snow shield; - Speed measuring point.

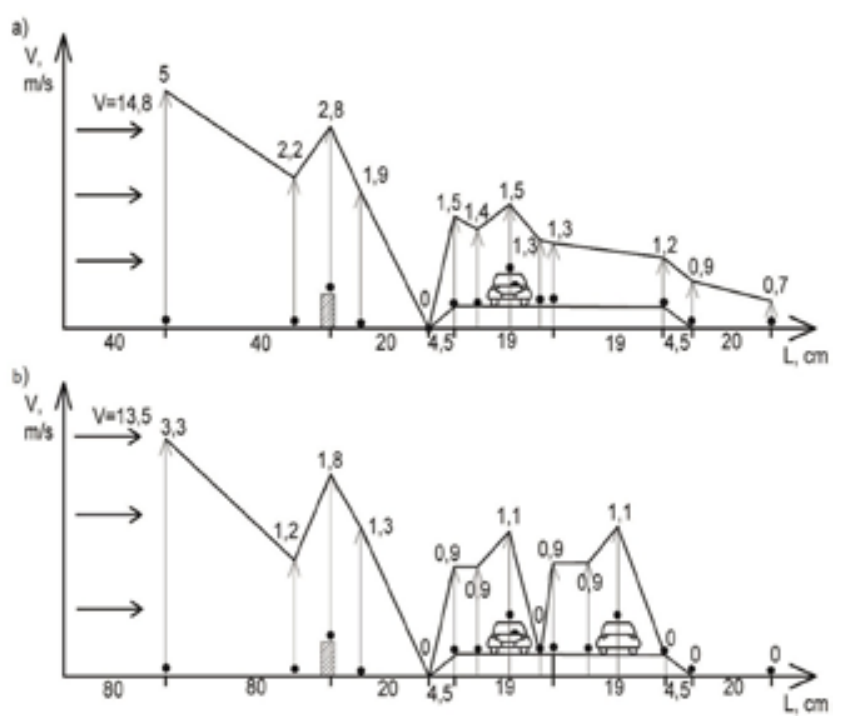

Fig. 5. Graphs reflecting change in speed of the air flow over the road embankment with a snow shield and cars moving on the traffic-bearing surface with: a) one-lane traffic; b) two-lane traffic; - - Speed measuring point. 


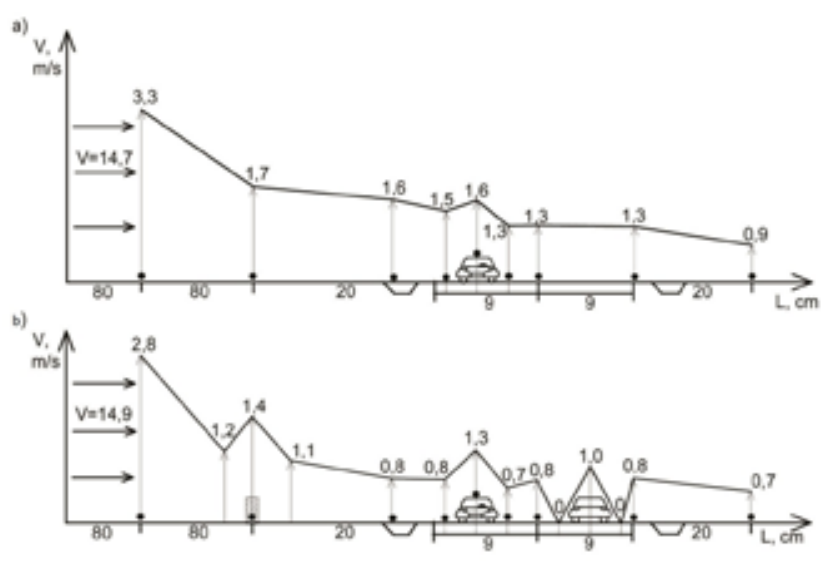

Fig. 6. Graphs reflecting change in speed of the air flow over the road with traffic-bearing surface at ground level with: a) one-lane traffic, no snow shield; b) two-lane traffic, with a snow shield; - - Speed measuring point.

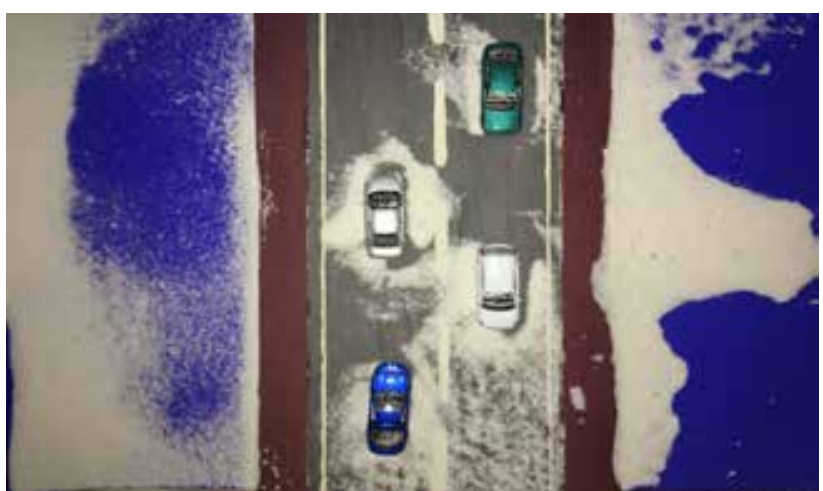

Fig. 7. Deposition of solid particles from the air flow on the model of the road with traffic-bearing surface on an embankment. One-lane traffic.

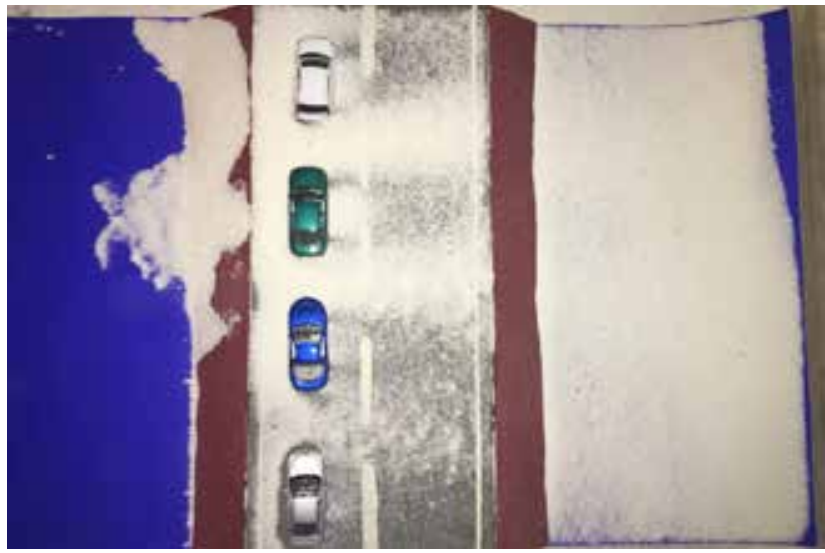

Fig. 8. Deposition of solid particles from the air flow on the model of the road with traffic-bearing surface on an embankment. Two-lane traffic.

\subsection{Partial Conclusions}

Changes in the air speed over traffic-bearing surface of the road showed that in ground blizzard (air flow height up to $2 \ldots 3 \mathrm{~m}$ ) car flow on the surface of the road contributes to blizzard drifts and therefore formation of snow drifts. Regardless whether there is a snow-retaining barrier in front of the road or not. These natural phenomena do not change regardless of the climate changes, they shall be treated as a fact. Busy traffic on the roads that was formed during the motorization of society and that is not expected to decrease in the foreseeable future shall also be treated as a fact. These facts make winter maintenance of motorways an extremely important issue. The most important being protection of traffic bearing surface of the road against snow sedimentation.

\section{RECOMMENDATIONS}

Prevention of blizzard depositions on the existing roads may be ensured by enhancing the protection system - by installing blow-over fences at the edge of the roads or at the top of the slope (close to the sod line) of the road-bed or by construction of permanent or temporary (easily assembled, transparent materials use is possible) smoothly streamed snow protection galleries. New motorways shall be constructed with embedded snow protection, i.e. so that blizzard depositions cannot form on the traffic bearing surface of the road.

New snow removal conditions also require technical improvement of snowploughs. Snow ploughs shall be equipped with blades with configuration that contributes to the formation of snow vortexes to throw snow as far away as possible, for example, by changing the shape of the blade and equipping the snow plough with a fan or air cannon. During snowfalls and blizzards with high wind speed it is feasible to change the principle of snow removal with a snow plough - instead of moving and throwing it away a blow-away principle may be employed strong airstream may be used - like a jet one, but with a low heating temperature (or without any heating). The Russian Federation has a certain experience in using aeroplane jet engines past their code-specified expiry date for removing snow and ice from roads.

An important aspect of snow protection (as part of winter roads maintenance) in introduction of a new traffic control regime: control of speed and overtaking, prohibition (temporary restriction) of driving during snowfalls and blizzards. This will require cooperation with neighbouring road operation institutions. The main thing during emergency situations is to inform and warn drivers about a high risk of snow jams and their effect on cars movement and control (regimes and speed). 


\section{REFERENCE}

[1] Nemchinov M.V., Vasilyeva A.G.: Ways to reduce the excavations in motor roads construction, Moscow State University of Road Traffic (MADI) Herald, 2016, 2 (45), pp. 62-70.

[2] Nemchinov M.V.: Protection of small-scale artificial structures from local erosion. Scientific and technical report, No. 745, M.: MADI, 1964, p. 115.

[3] Bolshakov V.A.: Hydrotechnical structures at motor roads, M.: Transport, 1965, p. 320.

[4] Duncan C.S.: Revenue For Highway Construction And Maintenance. Annals of the American Academy of Political and Social Science, 1934, t. 171, No. 1, pp. 244-252.

[5] Kolisoja P., Kalliainen A.: Modelling of Plastic Culvert and Road Embankment Interaction in 3D, "Procedia Engineering" 2016, Vol. 143, pp. 427-434.

[6] Perminov A.N., Safonov I.P., Perminov N.A.: Innovtive Technology for Repair of Culverts in Conditions of Constant Intense Water Flow, "Procedia Engineering” 2017, Vol. 189, pp. 505-510.

[7] Villalva P., Reto D., Santos-Reis M., Revilla E., Grilo C.: Do dry ledges reduce the barrier effect of roads? "Ecological Engineering", Vol. 57, August 2013, pp. 143-148.

[8] Fragkakis N., Marinelli M., Lambropoulos S.: Preliminary Cost Estimate Model for Culverts, "Procedia Engineering" 2015, Vol. 123, pp. 153-161.

[9] Kopanev I.D.: Snow cover study methods, L.: Hydrometeorological publishing, 1971.

[10] Byalobzhevsky G.V., Ivanov A.N., Shalman D.A.: Snow removal from motor roads. M.: Transport, 1972.

[11] Gedotov G.A., Pospelov P.I.: Survey and design of motor roads, Book 1, M.: Vyshaya Shkola, 2009.

[12] Designing motor roads. Highway engineer's handbook, M.: Transport, 1989.

[13] Highway engineer's handbook. Maintenance and repairs of motor roads, M.: Transport, 1974.

[14] Motor roads maintenance in winter time, ed. by A.K. Dyunin, M.: Transport, 1983.

[15] Nekrasov V.K., Aliev R.M.: Motor roads maintenance, M.: Vyshaya Shkola publishing, 1983.

[16] Nekrasov V.K.: Motor roads usage, M.: Vyshaya Shkola, 1970.

\section{Acknowledgments:}

The work was financed by Moscow automobile and road construction state technical, university

\section{Podziękowania:}

Praca była finansowana przez Moskiewski Techniczny Uniwersytet Samochodowy i Budowy Dróg 